\author{
Camelia Catalina JOLDES, PhD Student \\ E-mail: joldes.catalina@yahoo.com \\ The Bucharest University of Economics Studies
}

\title{
MODELING THE VOLATILITY OF THE BUCHAREST STOCK EXCHANGE USING THE GARCH MODELS
}

\begin{abstract}
This paper investigates the volatility of daily returns in the Romanian stock market over the period January 2005 to December 2017. Volatility is analysed using four stock market indices (BET, BETC, BETPlus and ROTX).We aimed in this article to identify an econometric model to shape volatility of our selected stock market indices. The analysis was carried out using GARCH models, very useful tools applied in financial economics. In the survey, the best model was identified for analysing the volatility of the stock market indices. The conditional volatility for the daily return series shows a clear evidence of volatility shifting over the period. In the course of the examination, we discovered that there is a great influence of international stock markets on the capital market operations in Romania.
\end{abstract}

Keywords: Romanian stock market, volatility clustering, autocorrelation, GARCH models, Granger causality.

\section{JEL Classification: C22, C32}

\section{Introduction}

Over time it was given high importance to the study of stock market evolution, especially volatility. Volatility is the degree to which the price of an investment fluctuates over a certain period of time, and is often associated with risk. Higher volatility is characterized by greater uncertainty.

Volatility increases in periods of economic or political instability or under the influence of certain factors. On the financial markets it was observed that the volatility changes differently according to the daily price variation of the respective financial asset. Observations have shown that downward movements of the market (in decreasing direction) are followed by a higher volatility than market upward movements of the same amplitude.

The aim of this paper is to evaluate the performance of various GARCH models using stock market indices that characterize the Bucharest Stock Exchange. These models simultaneously evaluate and test processes of yields and volatility processes. The importance of these models results from the difference between

DOI: $10.24818 / 18423264 / 53.1 .19 .18$ 
Camelia Catalina Joldes

conditional and unconditional variants. Unconditional variants are supposed to be time-independent and conditional variants are supposed to be dependent on past events that are included in the multitude of information at time $\mathrm{t}-1$.

\section{Literature Review}

A study which includes a systematic price analysis was done by Turner and Weigel (1992). They analysed the daily volatility of S\&P500 and Dow Jones indices returns for the 1928-1989 period, using standard deviation of returns, estimators which incorporate the daily high and low of the indices and also an estimator to measure the volatility of stock index returns. The authors observed that the days with extremely high returns are usually preceded by significant losses.

Murinde and Poshakwale (2001) examined the stock market volatility in Croatia, Czech Republic, Hungary, Poland, Russia and Slovakia, which are emerging markets from Europe. They applied ARIMA, the BDSL (Brock, Dechert, Scheinkman, and Le Baron's) procedure and symmetric/asymmetric GARCH models to test for daily return volatility. In all analysed markets, volatility exhibited significant conditional heteroskedasticity and non-linearity. The GARCH model was found to be the best in characterizing volatility in these markets. It was also tested the well-known day-of-the-week effect for the six emerging stock markets and did not appear to be present.

Kasch-Haroutounian and Price (2001) investigated the volatility transmission among stock markets in Central Europe (Czech Republic, Hungary, Poland and Slovakia) using BEKK model. Their estimation suggested that the volatility in the Polish stock market is affected by the volatility originating in the Hungarian stock market, but not in the opposite direction.

Frimpong and Oteng-Abayie (2006) modeled and quantified volatility of returns on the Ghanaian stock market with different types of GARCH models (from June 1994 to April 2004) and used a random walk (RW), GARCH (1,1), EGARCH $(1,1)$ and TGARCH $(1,1)$. For the Databank Stock Index (DSI) they found out specifics characteristics such as volatility clustering, leptokurtosis and asymmetry effects. The GARCH $(1,1)$ model outperformed the other models under the assumption that the innovations follow a normal distribution. The best model was GARCH $(1,1)$ model and the random walk hypothesis was rejected for the DSI.

Karmakar (2006) analysed capital market volatility in India, daily data for the period 1961-2005, using GARCH $(1,1)$ and TGARCH $(1,1)$ models. The analysis reports an evidence of variable volatility over time, showing high clustering, persistence and predictability, and asymmetric responses to positive and negative shocks.

Lupu and Lupu (2007) used an exponential model GARCH (E-GARCH) for the returns of the Romanian stock exchange index, BET-C. According to the 
Modeling the Volatility of the Bucharest Stock Exchange Using the GARCH Models

authors the purpose of the article was to model the statistical properties of BET-C returns in comparison with the main non-normality properties. They found that the E-GARCH model is a powerful model that can be used to forecast the volatility of stock market indexes.

Tudor (2008) implements symmetric GARCH models to study the volatility on the American (S\&P 500 index and KO stock) and Romanian (BET-C and TLV) stock markets, using daily logarithmic returns for January 2001 and February 2008. Tudor showed that GARCH $(1,1)$ models are correctly specified for the S\&P 500 index and KO, while for the BET-C index the model could not remove completely the heteroscedasticity from the residuals. Also the GARCH-inMean model showed that there is a positive relationship between risk and return for the series analysed, and in the case of the Romanian BET-C index, this relationship is stronger.

Surya Bahadur (2008) studied the volatility of the Nepalese stock market and the results indicated that the most appropriate model for volatility modeling was GARCH $(1,1)$. Also, the study pointed out evidence of time varying volatility and a high predictability of volatility in the Nepalese stock market.

Another study regarding the Romanian Capital market volatility was realized by Dima, Barna and Mura (2009) in which it was applied a GARCH framework in order to identify the structural changes. The authors conclude that the impact of factors (political instability or changes in the macroeconomic) on capital market have a high amplitude, generating a "short term functional" instability.

Mishra, Das and Pradhan (2009) used ARCH class models (GRACH, EGRACH and TGRACH models) to study the volatility of the Indian stock market during the 1991-2008 period. The TGARCH model had the best performance in estimating and predicting the volatility of the Indian capital market. Also the econometric estimations of the ARCH class models showed evidence of time varying volatility.

Panait and Slăvescu (2011) investigated how the Bucharest Stock Exchange (BSE) reacted during and after the crisis and how the volatility of the Romanian market evolved during 2007-2011, using correlation analysis and Granger causality tests. They found out a high degree of correlation between international markets and Romanian stock market during the analysed period, more precisely, during 2007-2008 it was higher, and in 2009-2011 it decreased slightly. Also they found a unidirectional causality from the international financial markets towards BSE.

Anton (2012) evaluate the forecasting performance of various GARCH models using daily data for BET index (from Bucharest Stock Exchange), for the period September 2001 to February 2012. According to information criteria and 
Camelia Catalina Joldes

log-likelihood function, Anton found out that TGARCH and $\operatorname{PGARCH}(1,2,1)$ are the most successful models.

Alexandru, Caragea and Dobre (2013) studied the volatility of the Romanian capital market (BET, BET-FI and BET-C as stock indices) through the $\mathrm{ARCH}$ and GARCH models using the "R" software (using the "rugarch" package). The authors find that the GARCH $(1,1)$ model is suitable for the BET index data series also they highlighted the utility of the statistical software used to process large-scale data series.

Another analysis of the Romanian stock market was carried out by Ghergut, Oancea and Căpățână (2013). They mainly studied the volatility of the BET-FI stock index using GARCH models from 2008 to 2013 (daily values). The EGARCH asymmetric model $(1,1)$ was considered to be the best model for analyzing the volatility of the BET-FI index.

\section{Data and methodology}

For our study we selected the most relevant market indices on the Bucharest Stock Exchange (BSE): BET (is the first index developed by BSE and the reference index of the local capital market), BET Plus (reflects the evolution of Romanian companies listed on the regulated market of BSE that meet the minimum selection criteria for liquidity and the value of the shares included in the free float), ROTX (is an index developed by BSE with Wiener Borse AG, which reflects in real time the movement of blue chip shares traded on the BSE) and BET-C (BET-C was a composite index of the BSE market and reflected the evolution of the prices of all listed companies on the BSE regulated market, Category I and II, it ceased to exist on 23 June 2014 and a new index, BET Plus was launched on the same date ). We also selected the 5 most liquid companies traded on the Romanian stock exchange: TLV (BancaTransilvania),BRD (BRD GroupeSociétéGénérale), SNP (OMV Petrom), FP (FondulProprietatea) and SNG (ROMGAZ SA). In order to capture the types of causality between foreign stock exchanges and Romanian stock exchange we have chosen to select four foreign indices such as: CAC 40 for the French stock market, DAX 30 for the Frankfurt Stock Exchange, FTSE 100 for the London Stock Exchange and S\&P500 for the New York Stock Exchange.

The data consist of daily observations. For BET, ROTX, CAC 40, DAX30, FTSE 100, S\&P500, TLV, BRD and SNP, the period analysedwas January 2005December 2017, BETPLUS: June 2014-December 2017, BETC: January 2005-June 2014, FP: January 2011-December 2017 and SNG: November 2013-December 2017and the data source was Thomson Reuters Datastream.

The formula for calculating daily returns is as follows:

$$
R_{i, t}=\ln \left(\frac{P_{i, t}}{P_{i, t-1}}\right)
$$


Modeling the Volatility of the Bucharest Stock Exchange Using the GARCH Models

where $R_{i, t}$ is the yield of the asset $\mathrm{i}$ in period $\mathrm{t}, P_{i, t}$ is the asset price $\mathrm{i}$ in period $\mathrm{t}$ and $P_{i, t-1}$ is the price of the asset in the t-1 period. According to scientific literature, preference is given to logarithmic yields, which were expected to show a normal distribution

The ARCH/GARCH models are used in the study of financial time series (e.g. evolution of sales prices, rate of return on financial assets, or exchange rates). These models simultaneously evaluate and test processes of yields and volatility processes. The importance of these models results from the difference between conditional and unconditional variants. Unconditional variants are supposed to be time-independent and conditional variants are supposed to be dependent on past events that are included in the multitude of information at time $t-1$.

ARCH models were introduced by Engle (1982) and Generalized (GARCH) by Bollerslev(1986). A GARCH model allows conditional variation to be dependent on its previous lags. GARCH models transform the AR process from the ARCH model into an ARMA process by adding a MA process. The GARCH model (p, q) has the form:

$$
\begin{aligned}
& y_{t}=\mu+\varepsilon_{t} \sim N\left(0, \sigma^{2}\right) \\
& \sigma^{2}=\omega+\alpha_{1} \varepsilon_{t-1}^{2}+\ldots+\alpha_{q} \varepsilon_{t-q}^{2}+\beta_{1} \sigma_{t-1}^{2}+\ldots+\beta_{p} \sigma_{t-p}^{2},
\end{aligned}
$$

where $\omega>0$ and $\alpha_{\mathrm{i}} \geq 0, \beta_{\mathrm{i}} \geq 0$.

From the above equations we can see that the conditioned variance of random perturbations depends both on the historical values of the shocks and on the values of the variance in the past. The coefficients of $\sigma_{t-p}^{2}$ represent persistence of volatility, and the coefficients of $\varepsilon_{t-p}^{2}$ represent the rate of reaction of volatility to shocks in the financial market. Parameter $\mathrm{p}$ is the order of the terms GARCH and $\mathrm{q}$ is the order of the ARCH terms.

Many researchers consider that a GARCH $(1,1)$ model is appropriate to model the evolution of volatility, but in this analysis we will study several extensions of the GARCH model. A GARCH model $(1,1)$ is equivalent to an $\mathrm{ARCH}$ (2) model, and a GARCH (p,q) model ( $p, q)$ is equivalent to an ARCH model ( $p+$ q).

Since the sum of the coefficients $\alpha$ and $\beta$ might be close to 1 for the GARCH model $(1,1)$, we can model the volatility using the IGARCH model (integrated GARCH). This model eliminates long-term volatility in the equation, requiring that the sum of the coefficients be 1 .

The ARCH model treats errors as symmetrical, that means positive and negative shocks affect the conditioned mode in the same way. However, the shock response may be asymmetric. An EGARCH model (exponential GARCH)(this 
model was introduced by Nelson in 1991) allows shocks to have asymmetric effect on conditional variants. The effect of information is no longer considered square but exponential. For the EGARCH model $(1,1)$, the variance equation can be written as:

$$
\log \left(\sigma_{t}^{2}\right)=\omega+\beta \log \left(\sigma_{t-1}^{2}\right)+\alpha \frac{\left|\varepsilon_{t-1}\right|}{\sigma_{t-1}}+\gamma \frac{\varepsilon_{t-1}}{\sigma_{t-1}}
$$

Here $\gamma$ is the measure of leverage effect. If $\gamma>0$ we say that there is leverage and if $\gamma \neq 0$, the impact of the news is asymmetric.

The TGARCH models (Threshold GARCH) were introduced by Glosten, Jagannathan and Runkle (1993). For the TGARCH model $(1,1)$, the variance equation can be written as:

$$
\sigma_{t}^{2}=\omega+\alpha \varepsilon_{t-1}^{2}+\beta \sigma_{t-1}^{2}+\gamma \varepsilon_{t-1}^{2} I_{t-1}
$$

Where $\mathrm{I}_{\mathrm{t}-1}$ is a dummy variable, an indicator for negative innovations: $\mathrm{I}_{\mathrm{t}-1}=1$ if $\varepsilon_{\mathrm{t}-1}<0$ ("bad news" has an impact of $\alpha$ ) and $\mathrm{I}_{\mathrm{t}-1}=0$ if $\varepsilon_{\mathrm{t}-1} \geq 0$ ("good news" has an impact of $\alpha+\gamma)$. If $\gamma>0$ we say that there is leverage and if $\gamma \neq 0$, the impact of the news is asymmetric.

Another asymmetric model is APARCH model (Asymmetric Power GARCH), which was introduced by Ding, Granger and Engle (1993). The variance equation can be written as:

$$
\sigma_{t}^{\delta}=\omega+\alpha\left(\left|\varepsilon_{t-1}\right|+\gamma \varepsilon_{t-1}\right)^{\delta}+\beta \sigma_{t-1}^{\delta}
$$

In order to analyse the causality between capital markets, we can use the Granger causality test, which is used by many authors. To be able to perform this causality test, the data series must be stationary and zero average.

Initially we will study both the stationarity of the data unit root tests and their order of integration. We will use the Augmented Dickey-Fuller test to checkADF stationarity. Augmented Dickey Fuller is used to determine the order of integration, and the null hypothesis is the existence of a unit root.

\section{Results}

The table below shows descriptive statistics of daily logarithmic returns of the Bucharest Stock Exchange indices. The return series is negatively skewed (with the exception of BRD share). Specific situation of financial markets, Skewness is negative indicating an asymmetry to the left.

Table 1. Descriptive Statistics for Daily Logarithmic Returns

\begin{tabular}{|l|c|c|c|c|c|c|c|c|c|}
\hline & BET & BET-C & BETPLUS & ROTX & BRD & FP & SNG & SNP & TLV \\
\hline Mean & 0.000167 & $6.66 \mathrm{E}-05$ & 0.000155 & 0.000183 & 0.000162 & 0.000280 & $-8.26 \mathrm{E}-05$ & $-4.46 \mathrm{E}-05$ & 0.000598 \\
\hline Maximum & 0.105645 & 0.108906 & 0.061292 & 0.104292 & 0.281896 & 0.055086 & 0.048348 & 0.137422 & 0.260522 \\
\hline Minimum & $-0.131168-0.121184$ & -0.064836 & -0.196532 & -0.158724 & -0.074018 & -0.128442 & -0.162101 & -0.867814 \\
\hline Std. Dev. & 0.015346 & 0.015818 & 0.008082 & 0.016338 & 0.022065 & 0.011031 & 0.011927 & 0.021573 & 0.025752 \\
\hline Skewness & $-0.690474-0.752149$ & -0.886707 & -1.005463 & 0.244464 & -0.238958 & -2.451779 & -0.303233 & -11.23426 \\
\hline
\end{tabular}


Modeling the Volatility of the Bucharest Stock Exchange Using the GARCH Models

\begin{tabular}{|l|c|c|c|c|c|c|c|c|c|}
\hline Kurtosis & 13.01521 & 11.86516 & 17.52583 & 16.94950 & 18.40720 & 8.543359 & 25.37394 & 11.02416 & 393.2618 \\
\hline Jarque-Bera & 14369.23 & 8321.220 & 8057.199 & 27924.39 & 33405.55 & 2311.474 & 23215.24 & 9103.458 & 21482412 \\
\hline Probability & 0.000000 & 0.000000 & 0.000000 & 0.000000 & 0.000000 & 0.000000 & 0.000000 & 0.000000 & 0.000000 \\
\hline \multicolumn{6}{c|}{ Source: Datastream, authors' calculations }
\end{tabular}

The most interesting feature is the kurtosis, which measures the magnitude of the extremes, which is $>3$ and it suggests that the return series has fatter tails than the normal distribution. This feature is referred to as lepto-kurtosis, which could be caused by volatility clustering.

The value of the Jarque-Bera test and the probability attached to the test is $0 \%$. The test values are quite different from those of the normal distribution, which is why we can say that the series is not normally distributed.
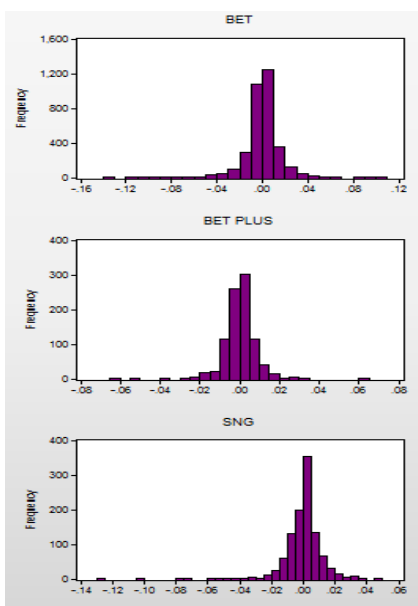
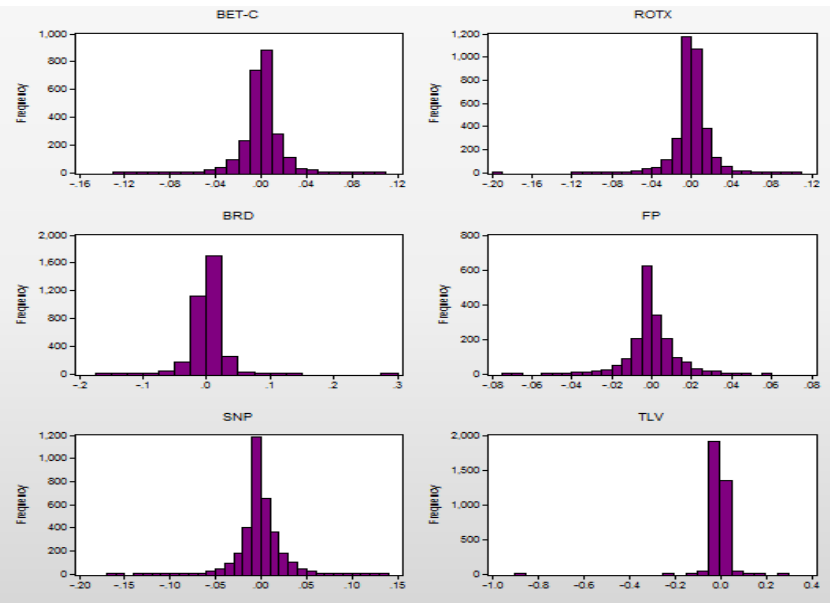

Figure 1. The density graphs

Source: Datastream, authors' calculations

Quantiles-Quantiles plot is a simple method used to compare two distributions, it represents the graph of an empirical distribution versus a theoretical distribution (the normal distribution). If the empirical distribution is normal, the resulting Q-Q graph should be the first bisector, but in our case the distribution is much different from the normal one. 

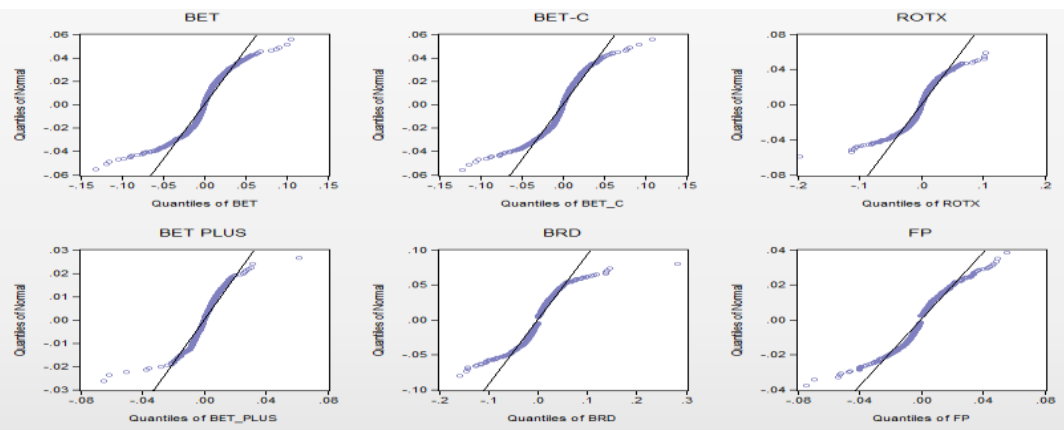

SNG
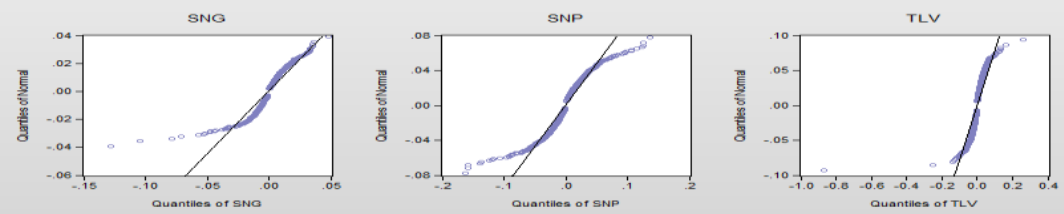

Figure 2.Q-Q plot

Source: Datastream, authors' calculations

The density graph and Q-Q plot against the normal distribution shows that the returns distribution also exhibits fat tails confirming the results in Table1.

We have examined the stationarity of the data series with the ADF (Augmented Dickey-Fuller), which is a method for testing stationarity (the null hypothesis is that the analysed data series is not stationary-has a root unit).

Table 2. ADF test results

\begin{tabular}{|c|c|c|c|c|c|}
\hline ADF & t-Statistic & Prob. & ADF & t-Statistic & Prob. \\
\hline BET & $\mathbf{- 5 3 . 7 7 5}$ & $\mathbf{1 . 0 0 E - 0 4}$ & BET-C & $\mathbf{- 4 4 . 9 3 1}$ & $\mathbf{1 . 0 0 E - 0 4}$ \\
\hline 1\%level & -3.432 & & $1 \%$ level & -3.433 & \\
\hline 5\%level & -2.862 & & $5 \%$ level & -2.863 & \\
\hline 10\%level & -2.567 & & $10 \%$ level & -2.567 & \\
\hline BETPLUS & $\mathbf{- 3 1 . 8 1 6}$ & $\mathbf{0}$ & ROTX & $\mathbf{- 5 3 . 9 3 5}$ & $\mathbf{1 . 0 0 E - 0 4}$ \\
\hline 1\%level & -3.437 & & $1 \%$ level & -3.432 & \\
\hline 5\%level & -2.865 & & $5 \%$ level & -2.862 & \\
\hline 10\%level & -2.568 & & $10 \%$ level & -2.567 & \\
\hline BRD & $\mathbf{- 5 4 . 5 8 8}$ & $\mathbf{1 . 0 0 E - 0 4}$ & FP & $\mathbf{- 4 1 . 3 4 4}$ & $\mathbf{0}$ \\
\hline 1\%level & -3.432 & & $1 \%$ level & -3.434 & \\
\hline 5\%level & -2.862 & & 5\%level & -2.863 & \\
\hline 10\%level & -2.567 & & $10 \%$ level & -2.568 & \\
\hline SNG & $\mathbf{- 3 3 . 5 4 8}$ & $\mathbf{0}$ & SNP & $\mathbf{- 5 7 . 2 9 7}$ & $\mathbf{1 . 0 0 E - 0 4}$ \\
\hline 1\%level & -3.436 & & $1 \%$ level & -3.432 & \\
\hline 5\%level & -2.864 & & 5\% level & -2.862 & \\
\hline 10\%level & -2.568 & & $10 \%$ level & -2.567 & \\
\hline FTSE100 & $\mathbf{- 2 7 . 9 8 9}$ & $\mathbf{0}$ & DAX 30 & $\mathbf{- 5 7 . 8 7 7}$ & $\mathbf{1 . 0 0 E - 0 4}$ \\
\hline 1\%level & -3.432 & & $1 \%$ level & -3.432 & \\
\hline
\end{tabular}


Modeling the Volatility of the Bucharest Stock Exchange Using the GARCH Models

\begin{tabular}{|c|c|c|c|c|c|}
\hline $5 \%$ level & -2.862 & & $5 \%$ level & -2.862 & \\
\hline $10 \%$ level & -2.567 & & $10 \%$ level & -2.567 & \\
\hline TLV & -60.006 & $1.00 E-04$ & S\&P500 & -45.62 & $1.00 E-04$ \\
\hline 1\%level & -3.432 & & $1 \%$ level & -3.432 & \\
\hline $5 \%$ level & -2.862 & & $5 \%$ level & -2.862 & \\
\hline $10 \%$ level & -2.567 & & 10\%level & -2.567 & \\
\hline CAC 40 & -36.846 & 0 & & & \\
\hline 1\%level & -3.432 & & & & \\
\hline $5 \%$ level & -2.862 & & & & \\
\hline $10 \%$ level & -2.567 & & & & \\
\hline
\end{tabular}

After applying ADF stationarity test, the analysed variables are $\mathrm{I}(0)$, also the stationarity of the series can be seen in the graphs below, where the daily returns of the analysed series are represented.
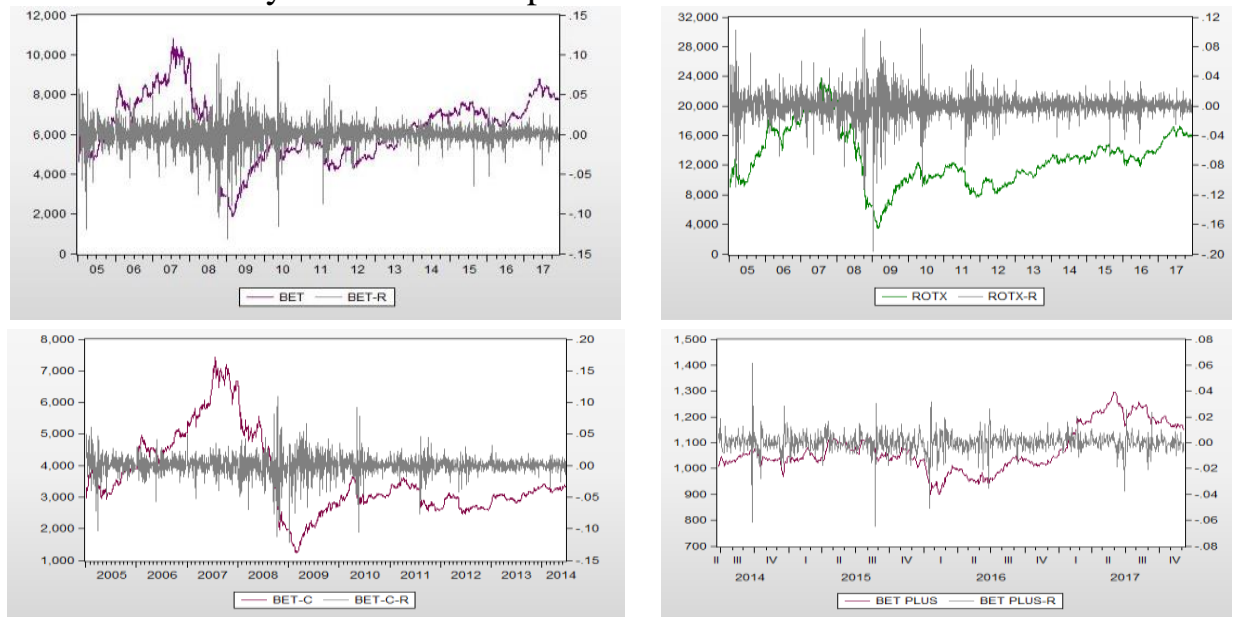

Figure 3. Daily values of the Romanian indexes Source: Datastream, authors' calculations

From the graphs above, we can see that there is a phenomenon of "volatility clustering" and an alternation between periods of low volatility and those with high volatility. Also"volatility clustering" implies a strong autocorrelation in returns. 

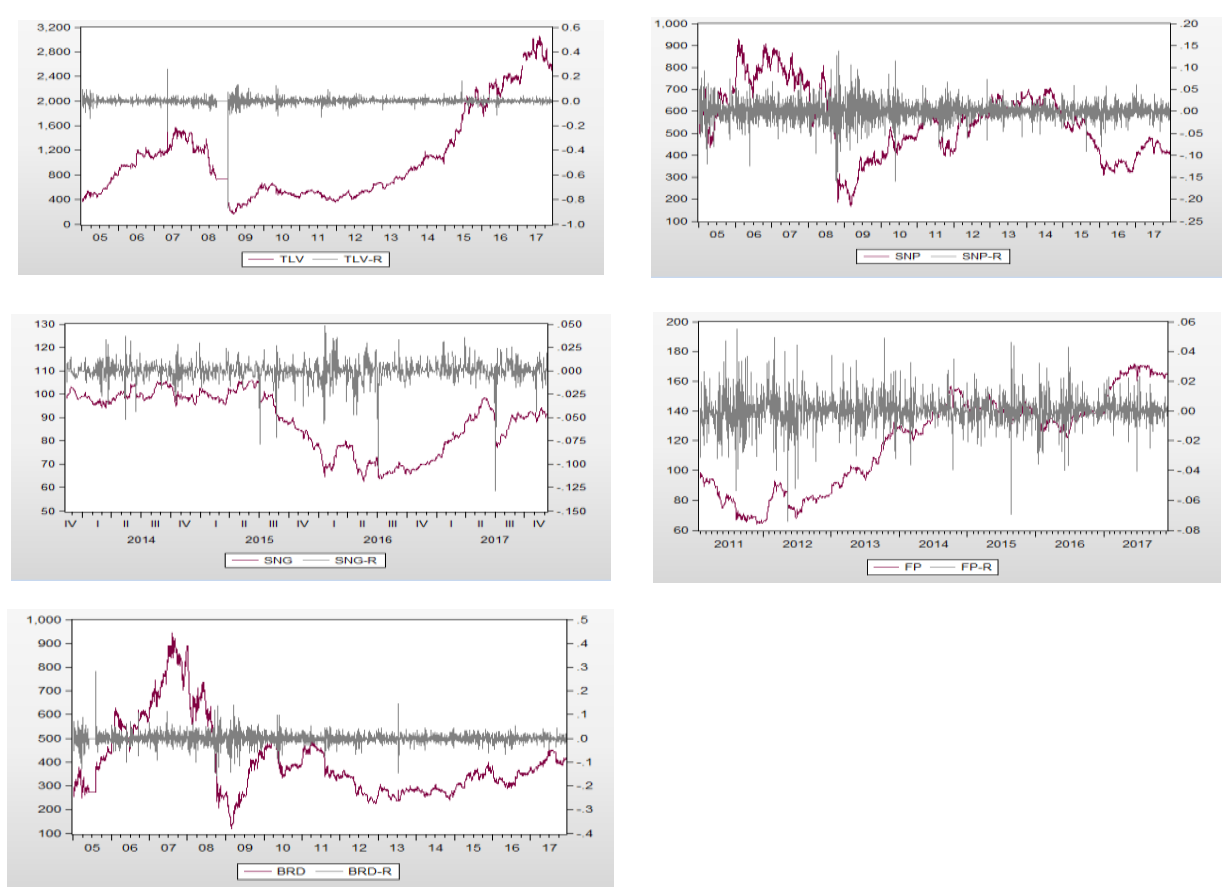

Figure 4. Daily values of the Romanian shares

Source: Datastream, authors' calculations

Before starting to perform GARCH models, it is necessary to perform preliminary tests to detect $\mathrm{ARCH}$ effects. We investigated the heteroscedasticity by calculating autocorrelation (AC), partial autocorrelation (PAC) and Q test. The number of lags used for all time series was 20 .

Table 3. Estimated autocorrelation (AC), partial autocorrelation (PAC) and Q-statistics with 20 lags for daily squared returns

\begin{tabular}{|l|c|c|c|c|c|}
\hline & Lag & AC & PAC & Q-Stat & Prob \\
\hline BET & 20 & 0.131 & 0.031 & 2052.0 & 0.000 \\
\hline BETC & 20 & 0.137 & 0.034 & 1610.3 & 0.000 \\
\hline BETPLUS & 20 & 0.003 & -0.004 & 111.47 & 0.000 \\
\hline BRD & 20 & 0.078 & 0.024 & 603.67 & 0.000 \\
\hline FP & 20 & 0.020 & -0.001 & 230.15 & 0.000 \\
\hline ROTX & 20 & 0.110 & 0.041 & 975.93 & 0.000 \\
\hline SNG & 20 & -0.006 & -0.005 & 55.462 & $\mathbf{0 . 9 9 9}$ \\
\hline SNP & 20 & 0.118 & -0.044 & 4367.3 & 0.000 \\
\hline TLV & 20 & -0.000 & -0.000 & 17.986 & $\mathbf{1 . 0 0 0}$ \\
\hline
\end{tabular}

Source: Datastream, authors' calculations 
Modeling the Volatility of the Bucharest Stock Exchange Using the GARCH Models

According to the results of the Q test, there is confirmed the existence of the serial correlation, heteroscedasticity (p-value less than $1 \%$ ), but in the case of the squared returns of SNG and TLV, the probability was greater than $1 \%$, the null hypothesis of the absence of the serial correlation up to lag 20 cannot be rejected in this case.

Therefore, the data series shows heteroscedasticity that can be modeled by GARCH models (except SNG and TLV, because heteroskedasticity is a precondition for applying GARCH models for financial time series, where we may not be able to match GARCH models).

The table below contains the estimated parameters for our chosen models and the information criteria (AIC and SBC).

Table 4. The results for the data series analysed:

\begin{tabular}{|c|c|c|c|c|c|c|}
\hline Model & $\overline{c(\omega)}$ & $\alpha$ & $\beta$ & $\gamma$ & AIC & SBC \\
\hline \multicolumn{7}{|c|}{ BET } \\
\hline GARCH $(1,1)$ & $4.05 \mathrm{E}-06(0.00)$ & $0.171756(0.00)$ & $0.820921(0.00)$ & - & -6.06598 & -6.05872 \\
\hline EGARCH $(1,1)$ & $-0.559638(0.00)$ & $0.311409(0.00)$ & $0.962616(0.00)$ & $-0.03511(0.00)$ & -6.04557 & -6.03649 \\
\hline TGARCH $(1,1)$ & $4.3 \mathrm{E}-060.0266)$ & $0.134594(0.00)$ & $0.818756(0.00)$ & $0.073233(0.00)$ & -6.07013 & -6.06106 \\
\hline PARCH $(1,1,1)$ & 7.2E-07(0.147) & $0.163904(0.00)$ & $0.804473(0.00)$ & $0.096608(0.00)$ & -6.07090 & -6.06001 \\
\hline PARCH $(1,2,1)$ & $1.6 \mathrm{E}-060.1367)$ & $0.227429(0.00)$ & $0.736773(0.00)$ & $0.102916(0.00)$ & -6.07667 & -6.06396 \\
\hline IGARCH $(1,1)$ & - & $0.081883(0.00)$ & $0.918117(0.00)$ & - & -6.02387 & -6.02024 \\
\hline \multicolumn{7}{|c|}{ BETC } \\
\hline GARCH $(1,1)$ & $4.80 \mathrm{E}-06(0.00)$ & $0.166195(0.00)$ & $0.823322(0.00)$ & - & -5.935265 & -5.925853 \\
\hline EGARCH $(1,1)$ & $-0.559668(0.00)$ & $0.299724(0.00)$ & $0.961098(0.00)$ & $-0.0192(0.003)$ & -5.907946 & -5.896181 \\
\hline TGARCH $(1,1)$ & $5.26 \mathrm{E}-06(0.00)$ & $0.151444(0.00)$ & $0.817804(0.00)$ & $0.033760(0.00)$ & -5.935416 & -5.923650 \\
\hline PARCH $(1,1,1)$ & $2.70 \mathrm{E}-7(0.2870)$ & $0.154967(0.00)$ & $0.798100(0.00)$ & $0.02978(0.104)$ & -5.937707 & -5.923589 \\
\hline PARCH $(1,2,1)$ & $8.43 \mathrm{E}-7(0.2517)$ & $0.212015(0.00)$ & $0.742886(0.00)$ & $0.02678(0.181)$ & -5.944617 & -5.928146 \\
\hline $\operatorname{IGARCH}(1,1)$ & - & $0.069180(0.00)$ & $0.930820(0.00)$ & - & -5.906055 & -5.901349 \\
\hline \multicolumn{7}{|c|}{ BETPLUS } \\
\hline GARCH $(1,1)$ & $2.52 \mathrm{E}-05(0.00)$ & $0.308878(0.00)$ & $0.324850(0.00)$ & - & -6.956506 & -6.935219 \\
\hline EGARCH $(1,1)$ & $-2.036969(0.00)$ & $0.236759(0.00)$ & $0.809758(0.00)$ & $-.168343(0.00)$ & -6.993957 & -6.967347 \\
\hline TGARCH $(1,1)$ & $2.19 \mathrm{E}-05(0.00)$ & $0.026239(0.45)$ & $0.399773(0.00)$ & $0.506198(0.00)$ & -6.996260 & -6.969650 \\
\hline PARCH $(1,1,1)$ & $0.000436(0.323)$ & $0.198442(0.00)$ & $0.487816(0.00)$ & $0.708232(0.00)$ & -6.996840 & -6.964909 \\
\hline PARCH $(1,2,1)$ & $0.000383(0.312)$ & $0.158091(0.00)$ & $0.652109(0.00)$ & $0.825228(0.00)$ & -6.998010 & -6.960756 \\
\hline $\operatorname{IGARCH}(1,1)$ & - & $-0.00078(0.00)$ & $1.000796(0.00)$ & - & -6.784113 & $\begin{array}{l}-6.773469 \\
\end{array}$ \\
\hline \multicolumn{7}{|c|}{ ROTX } \\
\hline GARCH $(1,1)$ & $5.43 \mathrm{E}-06(0.00)$ & $0.193121(0.00)$ & $0.804764(0.00)$ & - & -5.912431 & -5.905171 \\
\hline EGARCH $(1,1)$ & $-0.561679(0.00)$ & $0.331302(0.00)$ & $0.962611(0.00)$ & $0.00217(0.628)$ & -5.876149 & -5.867074 \\
\hline $\operatorname{TGARCH}(1,1)$ & $5.52 \mathrm{E}-06(0.00)$ & $0.188700(0.00)$ & $0.803369(0.00)$ & $0.01065(0.295)$ & -5.911922 & -5.902847 \\
\hline $\operatorname{PARCH}(1,1,1)$ & $6.15 \mathrm{E}-08(0.215)$ & $0.184188(0.00)$ & $0.754427(0.00)$ & $0.00652(0.598)$ & -5.918324 & -5.907434 \\
\hline $\operatorname{PARCH}(1,2,1)$ & $1.56 \mathrm{E}-07(0.192)$ & $0.232296(0.00)$ & $0.70523(0.00)$ & $0.00251(0.858)$ & -5.921797 & -5.909092 \\
\hline $\operatorname{IGARCH}(1,1)$ & - & $0.051998(0.00)$ & $0.948002(0.00)$ & & -5.888431 & -5.884801 \\
\hline \multicolumn{7}{|c|}{$\overline{B R D}$} \\
\hline $\operatorname{GARCH}(1,1)$ & $6.45 \mathrm{E}-05(0.00)$ & $0.168740(0.00)$ & $0.689823(0.00)$ & - & -5.051389 & -5.044129 \\
\hline EGARCH $(1,1)$ & $-2.498027(0.00)$ & $0.340870(0.00)$ & $0.709874(0.00)$ & $-0.05275(0.00)$ & -4.996194 & -4.987119 \\
\hline TGARCH $(1,1)$ & $6.31 \mathrm{E}-05(0.00)$ & $0.124111(0.00)$ & $0.698748(0.00)$ & $0.074820(0.00)$ & -5.053622 & -5.044547 \\
\hline $\operatorname{PARCH}(1,1,1)$ & $3.89 \mathrm{E}-07(0.251)$ & $0.126092(0.00)$ & $0.665051(0.00)$ & $0.089564(0.00)$ & -5.065918 & -5.055028 \\
\hline $\operatorname{PARCH}(1,2,1)$ & $4.36 \mathrm{E}-07(0.281)$ & $0.161535(0.00)$ & $0.563185(0.00)$ & $0.085811(0.00)$ & -5.068434 & -5.055729 \\
\hline $\operatorname{IGARCH}(1,1)$ & - & $0.014500(0.00)$ & $0.985500(0.00)$ & - & -5.038102 & -5.034472 \\
\hline \multicolumn{7}{|c|}{ FP } \\
\hline $\operatorname{GARCH}(1,1)$ & $7.29 \mathrm{E}-06(0.00)$ & $0.123722(0.00)$ & $0.821065(0.00)$ & - & -6.341382 & -6.329125 \\
\hline EGARCH $(1,1)$ & $-0.761825(0.00)$ & $0.213878(0.00)$ & $0.932857(0.00)$ & $-0.06458(0.00)$ & -6.341865 & -6.326543 \\
\hline TGARCH $(1,1)$ & $6.34 \mathrm{E}-06(0.00)$ & $0.061218(0.00)$ & $0.838099(0.00)$ & $0.110634(0.00)$ & -6.355410 & -6.340088 \\
\hline $\operatorname{PARCH}(1,1,1)$ & $1.98 \mathrm{E}-06(0.292)$ & $0.103095(0.00)$ & $0.832186(0.00)$ & $0.237653(0.00)$ & -6.354725 & -6.336340 \\
\hline $\operatorname{PARCH}(1,2,1)$ & $2.57 \mathrm{E}-06(0.278)$ & $0.116899(0.00)$ & $0.8133(0.00)$ & $0.242095(0.00)$ & -6.354203 & -6.332753 \\
\hline IGARCH $(1,1)$ & - & $0.041315(0.00)$ & $0.958685(0.00)$ & - & -6.287970 & -6.281842 \\
\hline \multicolumn{7}{|c|}{ SNP } \\
\hline $\operatorname{GARCH}(1,1)$ & $1.04 \mathrm{E}-05(0.00)$ & $0.102579(0.00)$ & $\begin{array}{l}0.874621(0.00) \\
\end{array}$ & - & -5.170890 & -5.163630 \\
\hline EGARCH $(1,1)$ & $-0.262871(0.00)$ & $0.145275(0.00)$ & $0.979907(0.00)$ & $-0.03408(0.00)$ & -5.167804 & -5.158729 \\
\hline TGARCH $(1,1)$ & $9.40 \mathrm{E}-06(0.00)$ & $0.074302(0.00)$ & $0.885916(0.00)$ & $0.037379(0.00)$ & -5.172459 & -5.163384 \\
\hline
\end{tabular}


Camelia Catalina Joldes

\begin{tabular}{|l|l|l|l|l|l|l|}
\hline PARCH(1,1,1) & $4.08 \mathrm{E}-05(0.042)$ & $0.092634(0.00)$ & $0.899047(0.00)$ & $0.130209(0.00)$ & $\mathbf{- 5 . 1 7 3 5 3 2}$ & -5.162642 \\
\hline PARCH $(1,2,1)$ & $0.000103(0.024)$ & $0.146495(0.00)$ & $0.847966(0.00)$ & $0.115257(0.00)$ & $\mathbf{- 5 . 1 8 0 4 0 8}$ & $\mathbf{- 5 . 1 6 7 7 0 3}$ \\
\hline IGARCH(1,1) & - & $0.053274(0.00)$ & $0.946726(0.00)$ & - & $\mathbf{- 5 . 1 3 7 0 6 2}$ & -5.133432 \\
\hline
\end{tabular}

Source: Datastream, authors' calculations

We have only selected valid models, whose coefficients are statistically significant and different from 0 . According to the AIC and SBC, the lowest values were recorded by TGARCH $(1,1,1)$ and PARCH $(1,2,1)$ models, which means that these models are performing much better than others.

For these asymmetric GARCH models, the coefficient $\gamma$ is significantly different from zero implying that series are asymmetric and the leverage effects are present. In all cases, the positive value of the $\gamma$ indicates that good news increases the future volatility more than the bad news.Coefficients meet the conditions of the GARCH model, their sum being less than 1 . The coefficient $\alpha$ shows how quickly volatility adjusts based on market information, and $\beta$ refers to the persistence of volatility.

For these models we alsoanalysed the correlogram of the squared residuals, the ARCH test and the normality test. Therefore, the model residues are not autocorrelated, are homoskedastic and are not normally distributed (the results are presented in the appendix). Non-normality of the return distribution often happens for the residues of the models applied for the financial time series.

The volatility of the main stock index of the Bucharest Stock Exchange, BET, is shown in the following chart (for the other stock indices and shares, the graphs can be found in the annex). We generated the historical volatility series, based on the PGARCH $(1,2,1)$ equation.

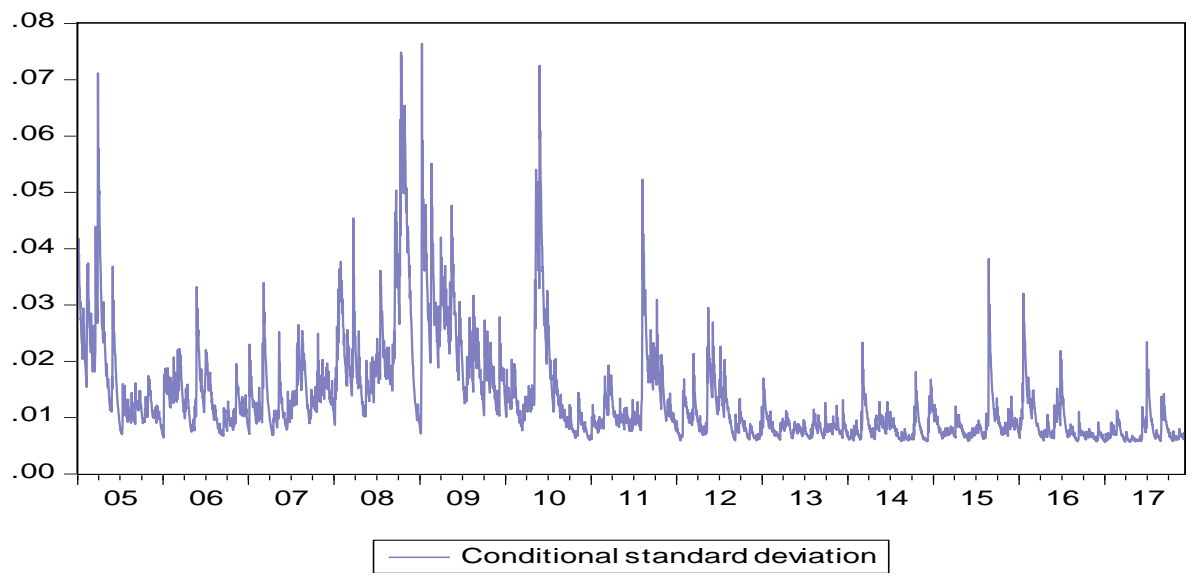

Figure 5. Conditional volatility of BET index

Source: Datastream, authors' calculations

Using the PGARCH $(1,2,1)$ model, we analysed the volatility of the BET index. As we can see, volatility was not neutral in the face of recorded economic or political events. The most pronounced volatility was noted in 2008-2009, followed 
Modeling the Volatility of the Bucharest Stock Exchange Using the GARCH Models

by a declining period, then, in 2010 , there was a steep rise in volatility, this evolution was due to the financial crisis. In 2011-2012 new volatility episodes were noticed, which decreased in the next period. Another significant volatility period took place in the third quarter of 2015 as a result of slower economic growth in China due to lower oil prices and geopolitical instability and the following took place in early 2016, due to the financial turbulence on the Asian stock exchanges and the one in June 2016 took place due to UK referendum. The most recent volatility episode occurred in July-August 2017 due to political instability at that time.

In order to detect short run causalities between major stock markets and Bucharest Stock Exchange we tested the Granger causality between Romanian stock market indices and four foreign indices such as: CAC 40, DAX 30,FTSE 100 and S\&P500 (it was used daily returns due to the actual speed of information flows and the number of lags used was 5).When causality is established, it suggests that one can use a variable, in this context the stock market index, to better predict the other variable, than simply the past history of the latter variable.

Table 5. The results of the Granger causality test

\begin{tabular}{|cccc|}
\hline $\begin{array}{c}\text { Null Hypothesis } \\
\text { Cause BET }\end{array}$ & Prob. & $\begin{array}{c}\text { Null Hypothesis } \\
\text { CAC40 does not Granger } \\
\text { Cause BETPLUS }\end{array}$ & Prob. \\
\hline $\begin{array}{c}\text { BET does not Granger Cause } \\
\text { CAC40 }\end{array}$ & 0.2493 & $\begin{array}{c}\text { BETPLUS does not Granger } \\
\text { Cause CAC40 }\end{array}$ & 0.1694 \\
\hline \hline $\begin{array}{c}\text { DAX30 does not Granger } \\
\text { Cause BET }\end{array}$ & $\mathbf{8 . E - 1 6}$ & $\begin{array}{c}\text { DAX30 does not Granger } \\
\text { Cause BETPLUS }\end{array}$ & 0.2803 \\
\hline $\begin{array}{c}\text { BET does not Granger Cause } \\
\text { DAX30 }\end{array}$ & 0.2705 & $\begin{array}{c}\text { BETPLUS does not Granger } \\
\text { Cause DAX30 }\end{array}$ & 0.1066 \\
\hline \hline $\begin{array}{c}\text { FTSE100 does not Granger } \\
\text { Cause BET }\end{array}$ & $\mathbf{2 . E - 1 3}$ & $\begin{array}{c}\text { FTSE100 does not Granger } \\
\text { Cause BETPLUS }\end{array}$ & $\mathbf{0 . 0 1 1 4}$ \\
\hline $\begin{array}{c}\text { BET does not Granger Cause } \\
\text { FTSE100 }\end{array}$ & 0.1415 & $\begin{array}{c}\text { BETPLUS does not Granger } \\
\text { Cause FTSE100 }\end{array}$ & $\mathbf{0 . 0 0 4 6}$ \\
\hline \hline $\begin{array}{c}\text { S\&P500 does not Granger } \\
\text { Cause BET }\end{array}$ & $\mathbf{5 . E - 5 9}$ & $\begin{array}{c}\text { SP500 does not Granger Cause } \\
\text { BETPLUS }\end{array}$ & $\mathbf{2 . E - 1 0}$ \\
\hline $\begin{array}{c}\text { BET does not Granger Cause } \\
\text { S\&P500 }\end{array}$ & $\mathbf{0 . 0 3 7 7}$ & $\begin{array}{c}\text { BETPLUS does not Granger } \\
\text { Cause SP500 }\end{array}$ & $\mathbf{0 . 0 0 6 1}$ \\
\hline \hline $\begin{array}{c}\text { BETC does not Granger Cause } \\
\text { CAC40 }\end{array}$ & 0.0816 & $\begin{array}{c}\text { CAC40 does not Granger } \\
\text { Cause ROTX }\end{array}$ & $\mathbf{3 . E - 1 7}$ \\
\hline $\begin{array}{c}\text { CAC40 does not Granger } \\
\text { Cause BETC }\end{array}$ & $\mathbf{1 . E - 1 4}$ & $\begin{array}{c}\text { ROTX does not Granger Cause } \\
\text { CAC40 }\end{array}$ & 0.3214 \\
\hline \hline $\begin{array}{c}\text { BETC does not Granger Cause } \\
\text { DAX30 }\end{array}$ & 0.2783 & $\begin{array}{c}\text { DAX30 does not Granger } \\
\text { Cause ROTX }\end{array}$ & $\mathbf{1 . E - 1 9}$ \\
\hline $\begin{array}{c}\text { DAX30 does not Granger } \\
\text { Cause BETC }\end{array}$ & $\mathbf{2 . E - 1 8}$ & $\begin{array}{c}\text { ROTX does not Granger Cause } \\
\text { DAX30 }\end{array}$ & 0.5609 \\
\hline \hline
\end{tabular}


Camelia Catalina Joldes

\begin{tabular}{|cccc|}
\hline $\begin{array}{c}\text { BETC does not Granger Cause } \\
\text { FTSE100 }\end{array}$ & 0.0577 & $\begin{array}{c}\text { FTSE100 does not Granger } \\
\text { Cause ROTX }\end{array}$ & 4.E-16 \\
\hline $\begin{array}{c}\text { FTSE100 does not Granger } \\
\text { CauseBETC }\end{array}$ & $\mathbf{2 . E - 1 3}$ & $\begin{array}{c}\text { ROTX does not Granger Cause } \\
\text { FTSE100 }\end{array}$ & 0.2300 \\
\hline \hline $\begin{array}{c}\text { BETC does not Granger Cause } \\
\text { SP500 }\end{array}$ & 0.0807 & $\begin{array}{c}\text { SP500 does not Granger Cause } \\
\text { ROTX }\end{array}$ & $\mathbf{8 . E - 7 0}$ \\
\hline $\begin{array}{c}\text { SP500 does not Granger Cause } \\
\text { BETC }\end{array}$ & $\mathbf{5 . E - 5 2}$ & $\begin{array}{c}\text { ROTX does not Granger Cause } \\
\text { SP500 }\end{array}$ & $\mathbf{0 . 0 3 2 4}$ \\
\hline
\end{tabular}

The results from the table above present some interesting evidence. We find a one-way relationship from CAC40 to BET, BETC and ROTX, from DAX30 to BET, BETC and ROTX, from FTSE100 to BET, BETC and ROTX, from S\&P500 to BETC. Therefore, we observe the existence of influences from the capital markets in France, Germany and Great Britain on daily returns of the Bucharest Stock Exchange.Interestingly, we found the presence of a bidirectional causality between the Romanian indices (BET, BETPLUS and ROTX) and S\&P500, so we have a basis to say that the Romanian stock market is significantly causing the daily returns of the American stock market.

\section{Conclusion}

This paper contributes to the existent literature because we have expanded the research area of volatility of the Bucharest Stock Exchange by approaching a number of four stock indices for a long period of time (January 2005 - December 2017) and using GARCH models. We also analysed whether international markets influence the Romanian stock market.

We found the distribution of the daily return series for the Romanian stock market to be leptokurtic, not normally distributed and exhibiting significant time dependencies. The TGARCH $(1,1,1)$ and PARCH $(1,2,1)$ were found to be the most appropriate models for volatility modeling in Romanian stock market. The study revealed strong evidence of time varying volatility, a tendency of the periods of high and low volatility to cluster and a high persistence of volatility on the Bucharest Stock Exchange.

Also, the aim of this research paper was to investigate the potential existence of international causal linkages between certain stock markets, such as Bucharest stock exchange (Romania), French stock market(France), Frankfurt Stock Exchange (Germany), London Stock Exchange (United Kingdom) and New York Stock Exchange (S.U.A.). The empirical results of Granger causality tests highlighted that Granger causality runs one way from France, Germany and United Kingdom to Romania and both ways between S.U.A and Romania.

The theme approached in this paper is of interest to both the investors and the academic side, which is why we intend to continue studying the volatility of the Bucharest Stock Exchange for different periods of time using other GARCH models. 
Modeling the Volatility of the Bucharest Stock Exchange Using the GARCH Models

\section{REFERENCES}

[1] Alexandru, A.C., Caragea, N., Dobre, A.M. (2013), Metode inovative de analiză a pieței de capital înRomânia. Studiul volatilităţii pieței de capital din România prin modelele ARCH şi GARCH utilizând softul „R”, Economie teoretică şi aplicată, Vol. XX, No. 11, pp. 4460; http://store.ectap.ro/articole/924_ro.pdf;

[2] Anton, S.G. (2012), Evaluating the Forecasting Performance of GARCH Models. Evidence from Romania; Procedia-Social and Behavioral Sciences, 62, pp.1006-1010; https://doi.org/10.1016/j.sbspro.2012.09.171;

[3] Bollerslev,T.(1986),Generalised Autoregressive Conditional

Heteroskedasticity; Journal of Econometrics 31, pp.307-327; https://doi.org/10.1016/0304-4076(86)90063-1;

[4] Dima, B., Barna, F., Mura, P.O. (2009), Analysis of the Romanian Capital Market Volatility; Theoretical and Applied Economics. Supplement; Finance and economic stability in the context of financial crisis, 10th International Conference, pp.613-618;

[5] Ding, Z., Granger, C.W.J., Engle, R.F. (1993), A Long Memory Property of Stock Market Returns and a New Model; Journal of Empirical Finance, No.1, pp.83-106;

[6] Engle, R.F. (1982), Autoregressive Conditional Heteroscedasticity with Estimates of the Variance of United Kingdom Inflation; Econometrica, Vol. 50, No.4, pp.987-

1007;https://www.jstor.org/stable/1912773?seq=1\#page_scan_tab_contents;

[7] Frimpong, J.M. and Oteng-Abayie, E.F. (2006), Modelling and Forecasting Volatility of Returns on the Ghana Stock Exchange Using GARCH Models; MPRA Paper, No. 593, pp.1-21;

[8] Ghergut, D.I, Oancea, B., Căpătână, C. (2013), Modelarea volatilitătii indicelui BET-FI, Romanian Statistical Review, Nr.7, pp.12-26;

http://www.revistadestatistica.ro/wpcontent/uploads/2014/02/RRS_07_2013_a3ro.pdf;

[9] Glosten, L., Jagannathan, R., Runkle, D. (1993), Relationship between the Expected Value and Volatility of the Nominal Excess Returns on Stocks; Journal of Finance, Vol.48, pp.1779-1802;

[10] Granger, C.W.J. (1969), Investigating causal relations by econometric models and cross-spectral methods; Econometrica, Vol. 37, No. 3., pp.424-438; https://www.jstor.org/stable/1912791;

[11] Gujarati, D.N. (2003), Basic Econometrics; Fourth Edition, McGraw-Hill Higher Education, pp.856-865; 
[12] Karmakar, M. (2006), Stock Market Volatility in the Long Run, 1961-2005; Economic and Political Weekly, Vol. 41, No. 18, pp.1796-1802;

[13] Kasch-Haroutounian, M.K., Price, S. (2001), Volatility in the Transition Markets of Central Europe; Applied Financial Economics, Vol.11, pp. 93105; https://doi.org/10.1080/09603100150210309;

[14] Lupu, R., Lupu, I. (2007), Testing for Heteroskedasticity on the Bucharest Stock Exchange; The Romanian Economic Journal, No.23, pp.19-28;

[15] Mishra, P.K., Das, K.B., Pradhan, B.B. (2009), Capital Market Volatility in India- An Econometric Analysis; The Empirical Economics Letters, 8(5), pp.450477;

[16] Murinde,V., Poshakwale, S. (2001), Volatility in the Emerging Stock Markets in Central and Eastern Europe: Evidence on Croatia, Czech Republic, Hungary, Poland, Russia and Slovakia; European Research Studies Volume IV (3-4), pp.73-101; https://www.ersj.eu/repec/ers/papers/01_34_p6.pdf;

[17] Nelson, D. B. (1991), Conditional Heteroskedasticity in Asset Returns: A New Approach; Econometrica, Vol. 59, No. 2, pp.347-

370; https://www.jstor.org/stable/2938260;

[18] Panait, I., Slavescu, O.E. (2011), Volatility and Causality Study of the Daily Returns on the Bucharest Stock Exchange during 2007-2011; MPRA Paper 41786, University Library of Munich, Germany;https://mpra.ub.unimuenchen.de/41786/;

[19] Surya Bahadur, G.C.(2008), Volatility Analysis of Nepalese Stock Market; The Journal of Nepalese Business Studies Vol. V, No. 1, pp.7684; https://ssrn.com/abstract=1565603;

[20] Tudor, C. (2008), Modelarea volatilitătii seriilor de timp prin modele GARCH simetrice; Romanian Economic Journal, Department of International Business and Economics from the Academy of Economic Studies Bucharest, Vol.11(30), pp.183-208;

[21] Turner, A.L.,Weigel, E.J. (1992), Daily Stock Market Volatility: 19281989; Management Science, Vol.38, No.11, Focused Issue on Financial Modeling, pp.1586-1609.

Annex

Table 1. Descriptive Statistics for Daily Logarithmic Returns

\begin{tabular}{|l|c|c|c|c|}
\hline & CAC40 & DAX30 & FTSE100 & S\&P500 \\
\hline Mean & 0.000102 & 0.000332 & 0.000124 & 0.000230 \\
\hline Median & 0.000184 & 0.000691 & $9.75 \mathrm{E}-05$ & 0.000349 \\
\hline Maximum & 0.105946 & 0.107975 & 0.093843 & 0.109572 \\
\hline Minimum & -0.094715 & -0.074335 & -0.092656 & -0.094695 \\
\hline Std. Dev. & 0.013797 & 0.013349 & 0.011398 & 0.011718 \\
\hline Skewness & -0.036985 & -0.038797 & -0.152046 & -0.357700 \\
\hline Kurtosis & 9.905680 & 9.624388 & 11.72574 & 15.55962 \\
\hline Jarque-Bera & 6704.965 & 6169.996 & 10716.80 & 22248.15 \\
\hline Probability & 0.000000 & 0.000000 & 0.000000 & 0.000000 \\
\hline
\end{tabular}


Modeling the Volatility of the Bucharest Stock Exchange Using the GARCH Models
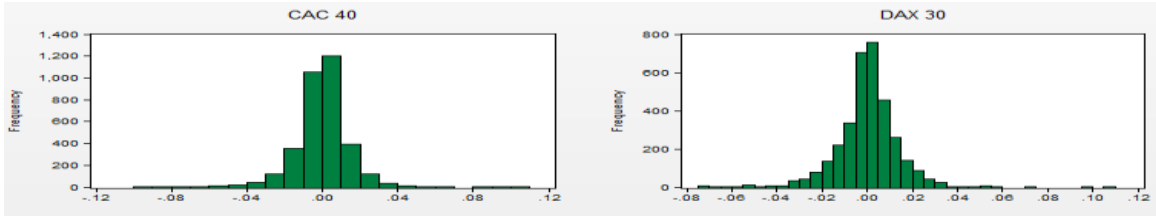

FTSE 100
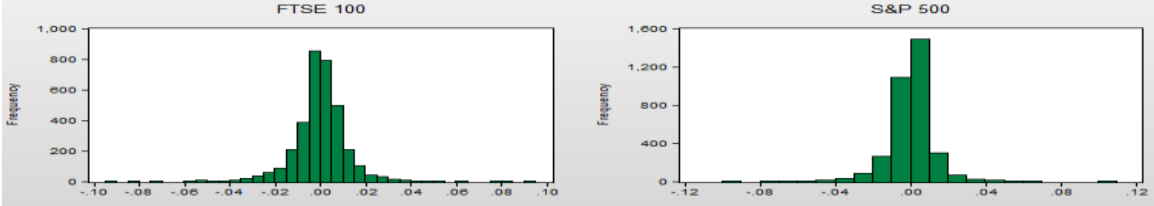

Figure1. The density graphs

Source: Datastream, authors' calculations
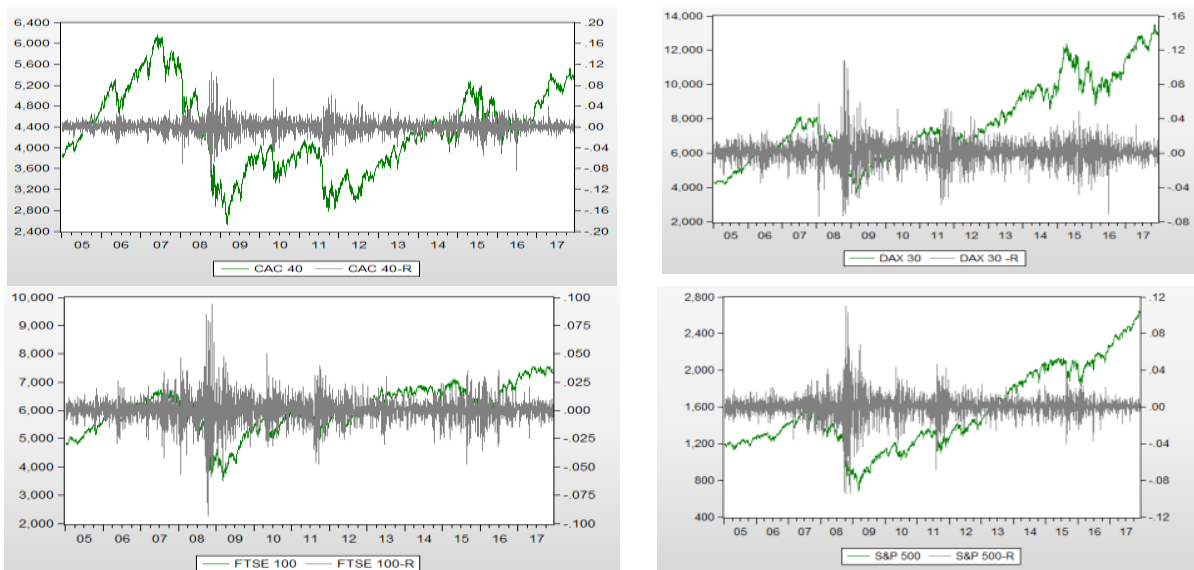

Figure2. Daily values of the international indexes Source: Datastream, authors' calculations

Table 2.Heteroskedasticity Test

\begin{tabular}{|c|c|c|c|}
\hline \multicolumn{5}{|c|}{ BET-TGARCH(1,1,1) } \\
\hline F-statistic & 8.67909 & Prob. F(1,3371) & 0.0032 \\
\hline Obs*R-squared & 8.661938 & Prob. Chi-Square(1) & 0.0032 \\
\hline \multicolumn{4}{|c|}{ BET-PARCH(1,2,1) } \\
\hline F-statistic & 0.734101 & Prob. F(1,3371) & $\mathbf{0 . 3 9 1 6}$ \\
\hline Obs*R-squared & 0.734377 & Prob. Chi-Square(1) & $\mathbf{0 . 3 9 1 5}$ \\
\hline \multicolumn{4}{|c|}{ BETC-PARCH(1,1,1) } \\
\hline F-statistic & 4.311124 & Prob. F(1,2467) & 0.038 \\
\hline Obs*R-squared & 4.307092 & Prob. Chi-Square(1) & 0.038 \\
\hline \multicolumn{5}{|c|}{ BETC-PARCH(1,2,1) } \\
\hline F-statistic & 1.351195 & Prob. F(1,2467) & $\mathbf{0 . 2 4 5 2}$ \\
\hline Obs*R-squared & 1.35155 & Prob. Chi-Square(1) & $\mathbf{0 . 2 4 5}$ \\
\hline \multicolumn{4}{|c|}{ BETPLUS-PARCH(1,2,1) } \\
\hline F-statistic & 0.10814 & Prob. F(1,900) & $\mathbf{0 . 7 4 2 3}$ \\
\hline Obs*R-squared & 0.108368 & Prob. Chi-Square(1) & $\mathbf{0 . 7 4 2}$ \\
\hline
\end{tabular}


Camelia Catalina Joldes

\begin{tabular}{|c|c|c|c|}
\hline \multicolumn{5}{|c|}{ ROTX-PARCH $(1,2,1)$} \\
\hline F-statistic & 0.53229 & Prob. F(1,3371) & $\mathbf{0 . 4 6 5 7}$ \\
\hline Obs*R-squared & 0.532522 & Prob. Chi-Square(1) & $\mathbf{0 . 4 6 5 5}$ \\
\hline \multicolumn{5}{|c|}{ BRD-PARCH(1,2,1) } \\
\hline F-statistic & 0.015722 & Prob. F(1,3371) & $\mathbf{0 . 9 0 0 2}$ \\
\hline Obs*R-squared & 0.015731 & Prob. Chi-Square(1) & $\mathbf{0 . 9 0 0 2}$ \\
\hline \multicolumn{4}{|c|}{ FP-TGRCH(1,1,1) } \\
\hline F-statistic & 2.391334 & Prob. F(1,1789) & $\mathbf{0 . 1 2 2 2}$ \\
\hline Obs*R-squared & 2.390812 & Prob. Chi-Square(1) & $\mathbf{0 . 1 2 2 1}$ \\
\hline \multicolumn{4}{|c|}{ SNP-PARCH(1,2,1) } \\
\hline F-statistic & 3.812443 & Prob. F(1,3371) & $\mathbf{0 . 0 5 1}$ \\
\hline Obs*R-squared & 3.810395 & Prob. Chi-Square(1) & $\mathbf{0 . 0 5 0 9}$ \\
\hline
\end{tabular}

Table 3. The correlograms of the squared residuals

\begin{tabular}{|l|c|c|c|c|c|}
\hline & Lag & AC & PAC & Q-Stat & Prob \\
\hline BET-PARCH $(1,2,1)$ & 20 & 0 & 0.001 & 23.732 & 0.254 \\
\hline BETC-PARCH $(1,2,1)$ & 20 & 0.003 & 0.005 & 23.128 & 0.283 \\
\hline BETPLUS-PARCH(1,2,1) & 20 & -0.009 & -0.01 & 5.0295 & 1 \\
\hline ROTX-PARCH $(1,2,1)$ & 20 & -0.001 & 0 & 17.898 & 0.594 \\
\hline BRD-PARCH $(1,2,1)$ & 20 & -0.001 & -0.001 & 0.5462 & 1 \\
\hline FP-TGRCH(1,1,1) & 20 & -0.003 & -0.003 & 13.72 & 0.844 \\
\hline SNP-PARCH $(1,2,1)$ & 20 & -0.004 & -0.004 & 15.196 & 0.765 \\
\hline
\end{tabular}

Source: Datastream, authors' calculations

BETC

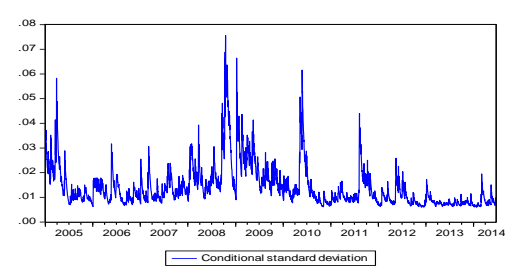

ROTX

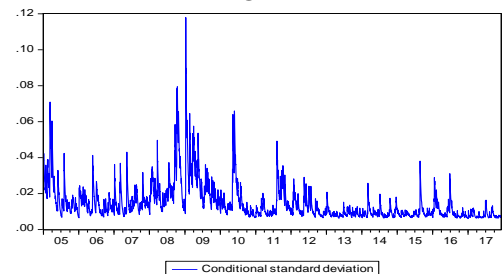

FP

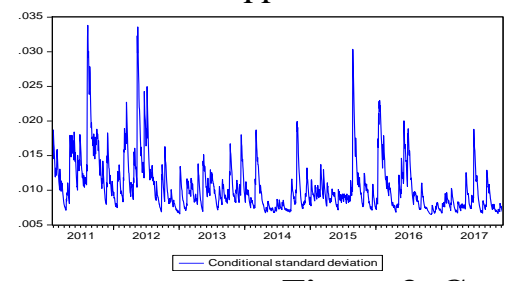

BETPLUS
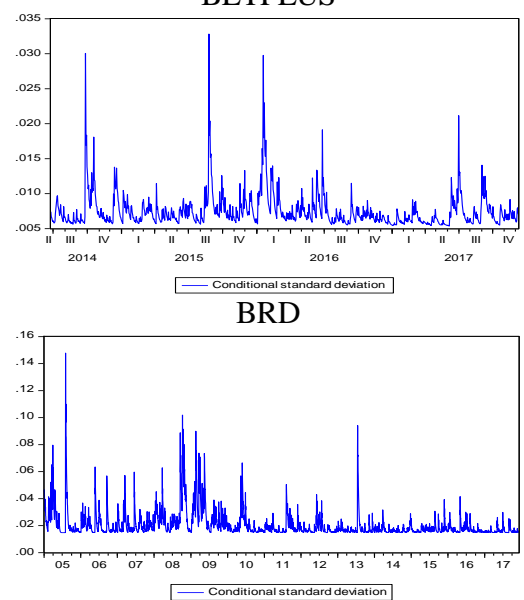

SNP

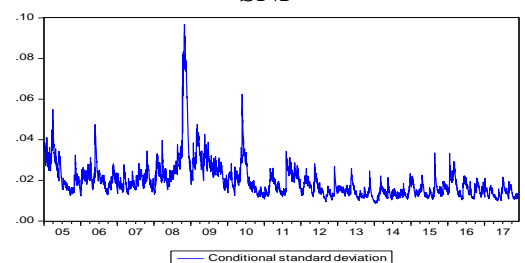

Figure 3. Conditional volatility

Source: Datastream, authors' calculations 